Portland State University

PDXScholar

\title{
Virtual Voices: Examining Social Support Exchanged Through Participant-Generated and Unmoderated Content in a Mobile Intervention to Improve HIV Antiretroviral Therapy Adherence Among GBMSM.
}

\author{
Christina J. Sun \\ OHSU-PSU School of Public Health, christina.sun@pdx.edu \\ Thembekile Shato \\ Washington University \\ Ashlynn Steinbaugh \\ Portland State University \\ Sharanya Pradeep \\ OHSU-PSU School of Public Health \\ Eollow this and additional works at: https://pdxscholar.library.pdx.edu/sph_facpub \\ KRIvet Amico \\ ivenstitofahenidgeibaime and Health Sciences Commons \\ Let us know how access to this document benefits you.
}

See next page for additional authors

Citation Details

Sun, Christina J.; Shato, Thembekile; Steinbaugh, Ashlynn; Pradeep, Sharanya; Rivet Amico, K; and Horvath, Keith, "Virtual Voices: Examining Social Support Exchanged Through Participant-Generated and Unmoderated Content in a Mobile Intervention to Improve HIV Antiretroviral Therapy Adherence Among GBMSM." (2022). OHSU-PSU School of Public Health Faculty Publications and Presentations. 481.

https://pdxscholar.library.pdx.edu/sph_facpub/481

This Post-Print is brought to you for free and open access. It has been accepted for inclusion in OHSU-PSU School of Public Health Faculty Publications and Presentations by an authorized administrator of PDXScholar. Please contact us if we can make this document more accessible: pdxscholar@pdx.edu. 
Authors

Christina J. Sun, Thembekile Shato, Ashlynn Steinbaugh, Sharanya Pradeep, K Rivet Amico, and Keith Horvath 


\section{Virtual voices: Examining social support exchanged through}

participant-generated and unmoderated content in a mobile intervention to improve HIV antiretroviral therapy adherence among GBMSM

Christina J. Sun ${ }^{1}$, Thembekile Shato ${ }^{2}$, Ashlynn Steinbaugh ${ }^{3}$, Sharanya Pradeep ${ }^{4}$, K. Rivet Amico 5 , Keith Horvath ${ }^{6}$

${ }^{1}$ School of Public Health, Oregon Health \& Science University-Portland State University, Portland, OR, USA; ${ }^{2}$ Implementation Science Center for Cancer Control, Washington University in St. Louis, St. Louis, MO, USA; ${ }^{3}$ Palo Alto University, Palo Alto, CA, USA $;{ }^{4}$ Boston Children's Hospital, Boston, MA, USA $;{ }^{5}$ Department of Health Behavior \& Health Education, University of Michigan, Ann Arbor, MI, USA; ${ }^{6}$ Department of Psychology, San Diego State University, San Diego, CA, USA

Christina J. Sun (corresponding author) chrsun@pdx.edu, tel: 503-725-8858, fax: 503725-5100, PO Box 751 Portland, OR 97207-0751 


\title{
Virtual voices: Examining social support exchanged through participant-generated and unmoderated content in a mobile intervention to improve HIV antiretroviral therapy adherence among GBMSM
}

\author{
Adherence to antiretroviral therapy (ART) is a key factor in reducing morbidity \\ and mortality for people living with HIV; however, rates are suboptimal among \\ gay, bisexual, and other men who have sex with men (GBMSM). Online and \\ technology-based interventions that incorporate social support represent new \\ opportunities to improve ART adherence. This study focused on how social \\ support was provided and sought through online messages GBMSM post within a \\ technology-based ART adherence intervention. We coded and analyzed 1,751 \\ messages. Within the social support messages, half of the time participants \\ sought social support and half of the time they provided social support. \\ Emotional and information support were the most frequently exchanged forms of \\ social support. The most frequent topic that participants sought social support \\ around was interpersonal relationships (29\%), followed by HIV care and \\ treatment (28\%), mental health (18\%), and substance use (12\%). Similarly, $31 \%$ \\ and $27 \%$ of messages in which participants provided social support were related \\ to HIV treatment and care and interpersonal relationships, respectively. The HIV \\ treatment and care issues most salient to GBMSM living with HIV were ART \\ adherence, HIV treatment lab results and upcoming tests, side effects from ARTs, \\ changes in their ART regimen, and the relationships they had with healthcare \\ providers. The message exchange feature in this intervention was used by \\ participants to spontaneously discuss topics relevant to, and exchange social \\ support around, HIV treatment and care. This analysis provided a unique \\ opportunity to understand how participants informally interact with one another, \\ the ways in which they seek and provide social support online, and the personal \\ issues that are most salient to them.
}

Keywords: social support; mHealth; ART adherence; men who have sex with men 


\section{Introduction}

Over 1 million people are living with HIV (PLWH) in the United States (US) (Centers for Disease Control and Prevention [CDC], 2018). Retention and engagement in HIV care, and adherence to antiretroviral therapy (ART), are key in reducing morbidity and mortality (Gardner et al., 2011; Mugavero et al., 2012). With ART adherence, PLWH have nearly the same life expectancy as people without (Antiretroviral Therapy Cohort Collaboration, 2008). Furthermore, sustained viral suppression reduces transmission risks (Cohen et al., 2011, 2016).

Gay, bisexual, and other men who have sex with men (GBMSM) are disproportionately affected by HIV, representing $61 \%$ of all PLWH and $69 \%$ of new diagnoses (CDC, 2018), despite accounting for approximately $2 \%$ of the US population (Purcell et al., 2012). Current HIV care retention and viral suppression rates (58\% and $61 \%$, respectively) (Singh et al., 2017) are much lower than the National HIV/AIDS Strategy objectives of $90 \%$ and $80 \%$, respectively (White House Office of National AIDS Policy, 2015). Increasing ART adherence is important to improve health of GBMSM.

One strategy to improve ART adherence is social support. Major types include emotional (i.e., emotional concern), informational (i.e., advice, guidance), instrumental (i.e., tangible aid such as goods or services), and appraisal (i.e., information for selfevaluation; House, 1981). Multiple types, measures, and sources of support are positively associated with ART adherence, lower viral load, and viral suppression (Burgoyne, 2005; Friedman et al., 2017; Kelly et al., 2014). Social support is one of the most impactful factors for adherence compared to a variety of sociodemographic, patient-related, treatment-related, condition-related, and interpersonal factors (Langebeek et al., 2014). Peer support interventions have positive impacts on ART adherence (Broadhead et al., 2002; Deering et al., 2009; Pearson et al., 2007; Simoni et 
al., 2009). As such, peer social support is included in recommendations and guidelines to improve ART adherence (Simoni et al., 2008; Thompson et al., 2012; Woodward \& Pantalone, 2012).

Online and technology-based interventions that incorporate social support represent new opportunities to improve ART adherence, as historically most ART adherence interventions occurred in person. Of the 19 medication adherence interventions in the CDC Compendium of Evidence-based Interventions and Best Practices for HIV Prevention (HIV/AIDS Prevention Research Synthesis Project, n.d.), 16 are in person.

Little is known about how social support functions in online interventions. Online interventions may expand a social support network. Anonymity can facilitate online support for persons living with stigmatized identities or health conditions (Tanis, 2008), including HIV, as they can connect with less risk. In some instances, online support provided additional benefits beyond in-person support, particularly for people with low levels of in-person support (Brandt \& Carmichael, 2020; Indian \& Grieve, 2014). However, the reduction of social cues in online settings impacts the quality of support (Rains, Akers, Pavlich, Tsetsi, \& Appelbaum, 2019). Researchers identified an association between in-person support and reduced depression, anxiety, and social isolation, but no such association for social support via social media (Meshi \& Ellithorpe, 2021). Aspects of social support received online remain poorly understood, despite increasing interest in and use of virtual modalities. The types of social support provided or exchanged are not well represented in the literature to date.

\section{Methods}

To better understand the types of social support present in online-socialnetwork-based approaches, we examined online message posts between participants in 
the Thrive With Me (TWM) intervention study where GBMSM with HIV were provided a messaging forum (Horvath et al., 2013, 2018). We examined messages to characterize the types of social support provided and sought within the technologybased ART adherence intervention.

\section{Setting and participants}

TWM was a virtual (i.e., online) behavioral intervention to improve ART adherence among GBMSM with HIV (Horvath et al., 2013, 2018). The main components were a private social networking feature; tailored HIV and ART adherence information and tips; and medication reminders, mood self-monitoring, and reflection. Participants interacted asynchronously by posting to the message board, where other users could react to or comment on messages. Message posting was the social support component of the intervention; participants directly and voluntarily interacted with one another in a similar manner as a face-to-face peer support group. All messages were participant generated.

A total of 401 GBMSM were recruited and 202 GBMSM were randomized to use TWM for 5 months. Participants were eligible if they currently identified as male; had sex with a man within the past year; were HIV infected; had a detectable viral load or potentially suboptimal ART adherence; were proficient in English; resided in the New York City metropolitan area; were able to send and receive SMS messages; and had internet access during study period (Horvath et al., 2018). The University of Minnesota Institutional Review Board approved all research activities.

\section{Data}

We examined messages that were "upvoted." Upvoted messages were those that another participant positively reacted to using a "like" function. Posts (i.e., message that began a discussion) that were upvoted and corresponding comments (i.e., response to a post) 
were coded. Given the volume, we focused on the messages posted during the first month each participant used TWM.

Demographics were collected using Qualtrics at baseline. Participants reported their age, race, ethnicity, highest level of education completed, and employments status. Participants also completed the Medical Outcomes Study (MOS) Social Support Survey (Sherbourne \& Stewart, 1991) to assess the availability of social support. Blood was drawn to assess plasma viral load.

\section{Codebook and coding}

The initial codebook was developed through an inductive and iterative approach by team members (KRA, AE, KH, TS). The first month's worth of messages from the first 50 intervention participants (October 2016 to January 2017) were iteratively reviewed to create a codebook, starting with familiarization, themes development, initial code application and then refinement.

Applying the codebook, all the posts that were upvoted and any corresponding comments were double coded by three coders (PS, AS, and TS). Any discrepancies in the coding were initially discussed within pairs and then when needed with the third coder and finally with the first author until consensus was reached. Microsoft Excel was used to organize the data.

\section{Analysis}

We calculated the inter-coder reliability (percentage of agreement between the two coders), and frequency and percentage of messages that contained a given code or subcode. For this paper, we focused on the social support codes (types: appraisal, emotional, information, instrumental; and function: providing or seeking) and HIV care codes (adherence, treatment, healthcare).

\section{Results}




\section{Participant characteristics}

Participants were on average 40 years old and $61 \%$ identified as African American or

Black (see Table 1). Most participants were unemployed (38\%) or disabled (17\%). Approximately two-thirds (63\%) had an undetectable viral load.

\section{[Table 1 near here]}

\section{Message characteristics}

We analyzed 1,751 upvoted messages. Inter-coder reliability was 94\%. Fourteen percent $(n=241)$ of the messages were coded as social support (Table 2$)$ and $11 \%(n=187)$ were coded as HIV treatment and care (Table 3).

\section{Social support (Table 2)}

Within social support messages, half $(n=120)$ of the time participants sought social support and half $(\mathrm{n}=121)$ of the time they provided social support. Emotional and information support were the most frequently exchanged forms. Emotional support was exchanged in $57 \%(n=137)$ of the support messages and informational support was exchanged in $50 \%(n=121)$ of the support messages (participants could provide or seek more than one form of support within each message). No participants requested or provided instrumental support. There were slightly more instances of participants seeking emotional support $(n=79)$ than providing $(n=58)$ it, but the reverse was true for informational support ( $n=69$ messages provided informational support while $n=52$ messages that sought informational support).

\section{[Table 2 near here]}

Participants sought support around many different topics. The most frequent topic was interpersonal relationships (29\% of all messages coded as seeking social support; $\mathrm{n}=35 / 120)$, followed by HIV care and treatment $(28 \% ; n=33 / 120)$, mental health $(18 \% ; n=21 / 120)$, and substance use $(12 \% ; n=14 / 120)$. Similarly, $31 \%$ 
$(n=38 / 121)$ and $27 \%(n=27 / 121)$ of messages in which participants provided social support were related to HIV treatment and care and interpersonal relationships, respectively. This suggests that participants received support when they sought it.

When participants exchanged support around relationships, most messages were about current romantic partners and often overlapped with discussions of HIV status (see Table 2). In messages where participants sought support around mental health, participants expressed anxiety, disappointment, stress, or sadness. Participants seeking support for substance use described their sobriety or progress towards abstinence for a variety of different substances including alcohol and methamphetamine. A summary of the overlap between HIV treatment and care codes and support are described further below (see "HIV Treatment and Care" section).

\section{HIV treatment and care (Table 3)}

\section{ART Adherence}

There were three adherence sub-codes: adherence problems, adherence strategies, and other adherence. A quarter (24\%) of ART adherence messages were related to challenges taking ART including external factors (i.e., adherence problems). Participants openly shared instances when they were non-adherent to ART, including forgetting, not taking medication within a certain time period, or double dosing when they were unsure if they missed taking their medication, and sought informational support to help address adherence barriers. Participants also sought advice for specific situations that impacted adherence, such as privacy concerns when taking medication in public and the impact of job schedules on their adherence. In turn, participants responded by providing informational social support in the form of advice. 
Half $(50 \%)$ of messages coded as adherence contained tactics to improve adherence or remember to take medication (i.e., adherence strategies). Strategies included linking medication taking to other daily activities, setting reminders on phones, tracking medication with phone calendars, using pill cases, referring to ARTs as vitamins, and using TWM features (e.g., SMS reminders). It did not appear that participants used judgmental or blaming language in responses. In some responses, participants would "normalize" non-adherence by sharing they had done the same before giving suggestions to reduce non-adherence.

About one-third of messages were related to adherence, but not problems or strategies. For example, some participants shared and celebrated their successes with adherence. Participants responded with praise and encouragement. Within the "other adherence" subcode messages, participants discussed the importance of adherence. Participants linked adherence to staying healthy and alive. Some participants even expressed gratitude about the ease of their treatment for HIV compared to other health conditions.

\section{HIV treatment}

HIV treatment messages were primarily focused on discussing labs (13\%), side effects (26\%), and medication changes (24\%). Messages coded as labs focused on participants' most recent viral load and CD4 counts and upcoming lab work. For example, some participants celebrated good news. Participants also discussed interpreting values; for example, one participant described anxiety about his CD4 count and another participant provided support by encouraging him to follow his healthcare provider's interpretation and focus on whether results were in a healthy range instead on the exact value.

When discussing side effects, participants often named specific medications. Participants described side effects (e.g., hair loss, weight gain, diarrhea, lack of energy, 
upset stomach) and coping strategies, including taking medication at night so side effects occurred while asleep or utilizing medical marijuana.

Medication change messages included content about an actual, desired, or potential change in ARTs. There was often overlap between discussing medication change and side effects and similarly, participants often identified the medications by name. Some medication changes were welcomed and seen as beneficial by simplifying the regimen while others raised concerns about changes to a working regimen.

Other HIV treatment discussions related to labs, side effects, or medication changes included discussions of filling prescriptions and refills. For example, a participant sought suggestions on how to get a refill while being out of the country. Participants also discussed which resources made refills easier (e.g., patient portal) and difficulties with insurance companies not covering certain medications. Finally, some participants discussed current affairs and implications for HIV care.

\section{Healthcare}

There were two sub-codes for healthcare: healthcare provider (70\%) and other healthcare (30\%). Participants' relationships with various providers were discussed, including HIV providers, psychiatrists, other mental health providers, massage therapists, and case workers. When participants brought up concerns with their care, such as feeling dismissed or rushed during appointments, or a lack of caring, other participants problem solved by providing informational support such as the contact information for a preferred healthcare facility. In addition to wanting friendly service, participants discussed characteristics of HIV care that they were seeking, such as located nearby work, open outside of typical business hours, and being able to discuss decisions with their providers. Participants also posted messages about a variety of 
health concerns that were not necessarily related to HIV (e.g., sinus, cancer, grief, pain, depression).

\section{Discussion}

In this study, we examined the spontaneous messages GBMSM posted to their peers as part of a technology-based ART adherence intervention. This analysis provides a unique opportunity to explore how GBMSM informally interacted with one another, the ways they sought and provided social support online, and the personal issues that were most salient. Unlike in-person peer-to-peer support interventions where it is often uncommon to observe how social support is exchanged and what topics emerge from these discussions, this analysis allowed us to examine the messages peers posted to one another. We found when given the opportunity to communicate with peers, participants sought and provided social support online and spontaneously discussed ART adherence, HIV treatment, and healthcare.

Similar to observational studies of online HIV/AIDS support groups, we found emotional and informational support were the predominate forms (Coursaris \& Liu, 2009; Flickinger et al., 2017; Mo \& Coulson, 2008). Instrumental support was not requested or offered in our study. When instrumental support was provided, it was the least frequent form (Abbasi Shavazi et al., 2016; Coulson et al., 2007; Eichhorn, 2008). Previously identified HIV treatment and care instrumental support include a supportive person picking up medication, providing transportation, and helping with medication reminders (George et al., 2009), all of which typically involve in-person activities and both parties knowing one another. The nearly absent provision of instrumental support in the current study is likely driven, in part, by study restrictions on sending one-on-one messages, which curtailed sharing personally identifying contact information. However, the functionality of the intervention did not seem to hinder participants exchanging 
emotional and informational support. Participants demonstrated care and empathy to one another and provided suggestions and advice through their messages.

We also examined what HIV treatment and care issues were most salient to GBMSM with HIV as reflected in their spontaneously generated conversations. Participants discussed their ART adherence, HIV treatment lab results and upcoming tests, ART side effects, ART regiments, and relationships with healthcare providers. Participants not only discussed challenges, but also celebrated successes in adherence and positive outcomes such as improved immune functioning. Similar to other research, participants were concerned with managing side effects (Legrand et al., 2016). These findings further support the importance of patient-provider relationships (Jaiswal et al., 2018; Oetzel et al., 2015; Roberts, 2002; Schneider et al., 2004) and suggest interventions that improve patient-provider communication about or encourage providers to discuss side effects or engage in patient-centered decision making could be helpful. Consistent with previous findings, structural barriers (Holtzman et al., 2015; Kalichman et al., 2017), such as challenges navigating insurance and healthcare systems, were reflected in the discussions of GBMSM in this study. Healthcare organizational-level changes to make medication prescription filling and refills easier are needed.

Outside of HIV care, the other most frequent areas participants sought support were interpersonal relationships, mental health, and substance use. The popularity of these topics complements existing research that described elevated rates of substance use, depression, and anxiety among GBMSM with HIV (Boarts et al., 2006; Bourne \& Weatherburn, 2017; Cochran et al., 2003; Cochran \& Mays, 2000; Sanchez et al., 2018). While existing research described the association between HIV transmission and substance use, we found that participants sought support for reducing substance use. 
HIV stigma was evident in GBMSM's interpersonal relationships as they discussed struggles with issues like disclosure. These findings add to the literature by increasing our understanding of the source of mental health concerns and how interpersonal relationships, particularly those with partners, shape the lives of GBMSM.

There are several limitations. We only examined upvoted posts and associated comments from the first month. It is possible that the types of support exchanged or content discussed differ over time or among non-upvoted posts. Participants were recruited from one urban area and findings may not be generalizable. This study does not include participants who have less access to technology (see inclusion criteria); they may seek social support differently than study participants.

Despite limitations, given the diversity of topics discussed, it appears the forum was a useful social support platform through which participants could seek advice and support from their peers. TWM discussions were unguided and unmoderated by study staff, a unique structure compared to other interventions (e.g., Hightow-Weidman et al., 2018). The message exchange feature in this intervention was used by participants to spontaneously discuss topics relevant to, and exchange social support around, HIV treatment and care. This type of analysis can be applied to other populations and health conditions to identify participant priorities. Further, online informational and emotional social support may be a critical form of support that some persons do not receive in their offline relationships. The level of social support available to participants appears to be somewhat lower than other prior studies of PLWH (Hightow-Weidman et al., 2017; McCoy et al., 2009). For those who experience HIV as a stigmatized health condition, they may not have members in their offline social support networks with whom to discuss their diagnosis and treatment, much less receive emotional support. Those with fewer opportunities for, or lower satisfaction with, offline support may rely more 
heavily on online supports, such as that made available through this intervention. Future research could examine whether online social support impacts PLWH differently depending on their offline support. The potential and impact of virtual peer-to-peer social support would benefit from continued examination.

Acknowledgements, This work was supported by the National Institutes of Health under Grant R01DA039950; and the Agency for Healthcare Research and Quality under Grant K12HS022981. 
References:

Abbasi Shavazi, M., Morowatisharifabad, M. A., Abbasi Shavazi, M. T., Mirzaei, M., \& Mellat Ardekani, A. (2016). Online social support for patients with multiple sclerosis: A thematic analysis of messages posted to a virtual support community. International Journal of Community Based Nursing and Midwifery, 4(3), 188-198.

Antiretroviral Therapy Cohort Collaboration. (2008). Life expectancy of individuals on combination antiretroviral therapy in high-income countries: A collaborative analysis of 14 cohort studies. The Lancet, 372(9635), 293-299. https://doi.org/10.1016/S0140-6736(08)61113-7

Boarts, J. M., Sledjeski, E. M., Bogart, L. M., \& Delahanty, D. L. (2006). The differential impact of PTSD and depression on HIV disease markers and adherence to HAART in people living with HIV. AIDS and Behavior, 10(3), 253-261. https://doi.org/10.1007/s10461-006-9069-7

Bourne, A., \& Weatherburn, P. (2017). Substance use among men who have sex with men: Patterns, motivations, impacts and intervention development need. Sexually Transmitted Infections, 93(5), 342-346. https://doi.org/10.1136/sextrans-2016052674

Brandt, S. A., \& Carmichael, C. L. (2020). Does online support matter? The relationship between online identity-related support, mattering, and well-being in sexual minority men. Computers in Human Behavior, 111. https://doi.org/10.1016/j.chb.2020.106429

Broadhead, R. S., Heckathorn, D. D., Altice, F. L., Van Hulst, Y., Carbone, M., Friedland, G. H., ... Selwyn, P. A. (2002). Increasing drug users' adherence to HIV treatment: Results of a peer-driven intervention feasibility study. Social Science and Medicine, 55(2), 235-246. https://doi.org/10.1016/S02779536(01)00167-8

Burgoyne, R. W. (2005). Exploring direction of causation between social support and clinical outcome for HIV-positive adults in the context of highly active antiretroviral therapy. AIDS Care - Psychological and Socio-Medical Aspects of AIDS/HIV, 17(1), 111-124. https://doi.org/10.1080/09540120412331305179

Centers for Disease Control and Prevention. (2018). HIV Surveillance Report, 2018 
(Updated) (Vol. 31). Retrieved from http://www.cdc.gov/hiv/library/reports/hivsurveillance.html

Cochran, S. D., \& Mays, V. M. (2000). Relation between psychiatric syndromes and behaviorally defined sexual orientation in a sample of the US population. American Journal of Epidemiology, 151(5), 516-523. https://doi.org/10.1093/oxfordjournals.aje.a010238

Cochran, S. D., Sullivan, J. G., \& Mays, V. M. (2003). Prevalence of mental disorders, psychological distress, and mental health services use among lesbian, gay, and bisexual adults in the United States. Journal of Consulting and Clinical Psychology, 71(1), 53-61. https://doi.org/10.1037/0022-006X.71.1.53

Cohen, M. S., Chen, Y. Q., McCauley, M., Gamble, T., Hosseinipour, M. C., Kumarasamy, N., ... Fleming, T. R. (2016). Antiretroviral therapy for the prevention of HIV-1 transmission. New England Journal of Medicine, 375(9), 830-839. https://doi.org/10.1056/NEJMoa1600693

Cohen, M. S., Chen, Y. Q., McCauley, M., Gamble, T., Hosseinipour, M. C., Kumarasamy, N., ... Team, H. 052 S. (2011). Prevention of HIV-1 infection with early antiretroviral therapy. New England Journal of Medicine, 365(6), 493-505. https://doi.org/10.1056/NEJMoa1105243

Coulson, N. S., Buchanan, H., \& Aubeeluck, A. (2007). Social support in cyberspace: A content analysis of communication within a Huntington's disease online support group. Patient Education and Counseling, 68(2), 173-178.

https://doi.org/10.1016/j.pec.2007.06.002

Coursaris, C. K., \& Liu, M. (2009). An analysis of social support exchanges in online HIV/AIDS self-help groups. Computers in Human Behavior, 25(4), 911-918. https://doi.org/10.1016/j.chb.2009.03.006

Deering, K. N., Shannon, K., Sinclair, H., Parsad, D., Gilbert, E., \& Tyndall, M. W. (2009). Piloting a peer-driven intervention model to increase access and adherence to antiretroviral therapy and HIV care among street-entrenched HIV-positive women in Vancouver. AIDS Patient Care and STDs, 23(8), 603-609. https://doi.org/10.1089/apc.2009.0022

Eichhorn, K. C. (2008). Soliciting and providing social support over the internet: An 
investigation of online eating disorder support groups. Journal of ComputerMediated Communication, 14(1), 67-78. https://doi.org/10.1111/j.10836101.2008.01431.x

Flickinger, T. E., DeBolt, C., Waldman, A. L., Reynolds, G., Cohn, W. F., Beach, M. C., ... Dillingham, R. (2017). Social Support in a Virtual Community: Analysis of a Clinic-Affiliated Online Support Group for Persons Living with HIV/AIDS. AIDS and Behavior, 21(11), 3087-3099. https://doi.org/10.1007/s10461-016-15873

Friedman, M. R., Coulter, R. W. S., Silvestre, A. J., Stall, R., Teplin, L., Shoptaw, S., ... Plankey, M. W. (2017). Someone to count on: social support as an effect modifier of viral load suppression in a prospective cohort study. AIDS Care Psychological and Socio-Medical Aspects of AIDS/HIV, 29(4), 469-480. https://doi.org/10.1080/09540121.2016.1211614

Gardner, E. M., McLees, M. P., Steiner, J. F., Del Rio, C., \& Burman, W. J. (2011). The spectrum of engagement in HIV care and its relevance to test-and-treat strategies for prevention of HIV infection. Clinical Infectious Diseases, 52. https://doi.org/10.1093/cid/ciq243

George, S., Garth, B., Wohl, A. R., Galvan, F. H., Garland, W., \& Myers, H. F. (2009). Sources and types of social support that influence engagement in HIV care among Latinos and African Americans. Journal of Health Care for the Poor and Underserved, 20(4), 1012-1035. https://doi.org/10.1353/hpu.0.0210

Hightow-Weidman, L., LeGrand, S., Choi, S. K., Egger, J., Hurt, C. B., \& Muessig, K. E. (2017). Exploring the HIV continuum of care among young black MSM. PLoS ONE, 12(6), 1-20. https://doi.org/10.1371/journal.pone.0179688

Hightow-Weidman, L., Muessig, K., Knudtson, K., Srivatsa, M., Lawrence, E., LeGrand, S., ... Hosek, S. (2018). A gamified smartphone app to support engagement in care and medication adherence for HIV-positive young men who have sex with men (AllyQuest): Development and pilot study. Journal of Medical Internet Research, 4(2), e34. https://doi.org/10.2196/publichealth.8923

HIV/AIDS Prevention Research Synthesis Project. (n.d.). Compendium of EvidenceBased Interventions and Best Practices for HIV Prevention. Retrieved July 2, 2020, from 
https://www.cdc.gov/hiv/research/interventionresearch/compendium/index.html

Holtzman, C. W., Shea, J. A., Glanz, K., Jacobs, L. M., Gross, R., Hines, J., ... Yehia, B. R. (2015). Mapping patient-identified barriers and facilitators to retention in HIV care and antiretroviral therapy adherence to Andersen's Behavioral Model. AIDS Care - Psychological and Socio-Medical Aspects of AIDS/HIV, 27(7), 817828. https://doi.org/10.1080/09540121.2015.1009362

Horvath, K. J., Amico, K. R., Erickson, D., Ecklund, A. M., Martinka, A., DeWitt, J., ... Parsons, J. T. (2018). Thrive With Me: Protocol for a Randomized Controlled Trial to Test a Peer Support Intervention to Improve Antiretroviral Therapy Adherence Among Men Who Have Sex With Men. JMIR Research Protocols, 7(5), e10182. https://doi.org/10.2196/10182

Horvath, K. J., Oakes, J. M., Rosser, B. R. S., Danilenko, G., Vezina, H., Amico, K. R., ... Simoni, J. (2013). Feasibility, acceptability and preliminary efficacy of an online peer-to-peer social support ART adherence intervention. AIDS and Behavior, 17(6), 2031-2044. https://doi.org/10.1007/s10461-013-0469-1

House, J. S. (1981). Work stress and social support. Addison-Wesley Publishing Company, Inc.

Huber, J., Muck, T., Maatz, P., Keck, B., Enders, P., Maatouk, I., \& Ihrig, A. (2018). Face-to-face vs. online peer support groups for prostate cancer: A cross-sectional comparison study. Journal of Cancer Surviorship, 12, 1-9. https://doi.org/10.1007/s11764-017-0633-0

Indian, M., \& Grieve, R. (2014). When Facebook is easier than face-to-face: Social support derived from Facebook in socially anxious individuals. Personality and Individual Differences, 59, 102-106. https://doi.org/10.1016/j.paid.2013.11.016

Jaiswal, J., Griffin-Tomas, M., Singer, S. N., \& Lekas, H. M. (2018). Desire for PatientCentered HIV Care Among Inconsistently Engaged Racial and Ethnic Minority People Living With HIV. Journal of the Association of Nurses in AIDS Care, 29(3), 426-438. https://doi.org/10.1016/j.jana.2018.01.001

Kalichman, S. C., Kalichman, M. O., \& Cherry, C. (2017). Forget about forgetting: structural barriers and severe non-adherence to antiretroviral therapy. AIDS Care Psychological and Socio-Medical Aspects of AIDS/HIV, 29(4), 418-422. 
https://doi.org/10.1080/09540121.2016.1220478

Kelly, J. D., Hartman, C., Graham, J., Kallen, M. A., \& Giordano, T. P. (2014). Social support as a predictor of early diagnosis, linkage, retention, and adherence to HIV care: results from the steps study. Journal of the Association of Nurses in AIDS Care, 25(5), 405-413. https://doi.org/10.1016/j.jana.2013.12.002

Langebeek, N., Gisolf, E. H., Reiss, P., Vervoort, S. C., Hafsteinsdóttir, T. B., Richter, C., ... Nieuwkerk, P. T. (2014). Predictors and correlates of adherence to combination antiretroviral therapy (ART) for chronic HIV infection: a metaanalysis. BMC Medicine, 12(1), 142. https://doi.org/10.1186/s12916-014-0142-1

Legrand, S., Muessig, K. E., Mcnulty, T., Soni, K., Knudtson, K., Lemann, A., ... Hightow-weidman, L. B. (2016). Epic Allies : Development of a Gaming App to Improve Antiretroviral Therapy Adherence Among Young HIV-Positive Men Who Have Sex With Men Corresponding Author: JMIR Serious Games, 4(1), e6. https://doi.org/10.2196/games.5687

McCoy, S. I., Strauss, R. P., MacDonald, P. D. M., Leone, P. A., Eron, J. J., \& Miller, W. C. (2009). Social support and delays seeking care after HIV diagnosis, North Carolina, 2000-2006. AIDS Care - Psychological and Socio-Medical Aspects of AIDS/HIV, 21(9), 1148-1156. https://doi.org/10.1080/09540120902730021

Meshi, D., \& Ellithorpe, M. E. (2021). Problematic social media use and social support received in real-life versus on social media: Associations with depression, anxiety and social isolation. Addictive Behaviors, 119. https://doi.org/10.1016/j.addbeh.2021.106949

Mo, P. K., \& Coulson, N. S. (2008). Exploring the communication of social support within virtual communities: A content analysis of messages posted to an online HIV/AIDS support group. CyberPsychology \& Behavior, 11(3), 371-374.

Mugavero, M. J., Amico, K. R., Westfall, A. O., Crane, H. M., Zinski, A., Willig, J. H., ... Saag, M. S. (2012). Early retention in HIV care and viral load suppression: Implications for a test and treat approach to HIV prevention. Journal of Acquired Immune Deficiency Syndromes, 59(1), 86-93. https://doi.org/10.1097/QAI.0b013e318236f7d2

Oetzel, J., Wilcox, B., Avila, M., Hill, R., Archiopoli, A., \& Ginossar, T. (2015). 
Patient-provider interaction, patient satisfaction, and health outcomes: Testing explanatory models for people living with HIV/AIDS. AIDS Care - Psychological and Socio-Medical Aspects of AIDS/HIV, 27(8), 972-978. https://doi.org/10.1080/09540121.2015.1015478

Pearson, C. R., Micek, M. A., Simoni, J. M., Hoff, P. D., Matediana, E., Martin, D. P., \& Gloyd, S. S. (2007). Randomized control trial of peer-delivered, modified directly observed therapy for HAART in Mozambique. Journal of Acquired Immune Deficiency Syndromes, 46(2), 238-244. https://doi.org/10.1097/QAI.0b013e318153f7ba

Purcell, D. W., Johnson, C. H., Lansky, A., Prejean, J., Stein, R., Denning, P., ... Crepaz, N. (2012). Estimating the population size of men who have sex with men in the United States to obtain HIV and syphilis rates. The Open AIDS Journal, 6(Suppl 1:M6), 98-107. https://doi.org/10.2174/1874613601206010098

Rains, S. A., Akers, C., Pavlich, C. A., Tsetsi, E., \& Appelbaum, M. (2019). Examining the quality of social support messages produced face-to-face and in computermediated communication: The effects of hyperpersonal communication. Communication Monographs, 86(3), 271-291. https://doi.org/10.1080/03637751.2019.1595076/FORMAT/EPUB

Roberts, K. J. (2002). Physician-patient relationships, patient satisfaction, and antiretroviral medication adherence among HIV-infected adults attending a public health clinic. AIDS Patient Care and STDs, 16(1), 43-50. https://doi.org/10.1089/108729102753429398

Sanchez, T. H., Zlotorzynska, M., Sineath, R. C., Kahle, E., Tregear, S., \& Sullivan, P. S. (2018). National Trends in Sexual Behavior, Substance Use and HIV Testing Among United States Men Who have Sex with Men Recruited Online, 2013 Through 2017. AIDS and Behavior, 22(8), 2413-2425. https://doi.org/10.1007/s10461-018-2168-4

Schneider, J., Kaplan, S. H., Greenfield, S., Li, W., \& Wilson, I. B. (2004). Better physician-patient relationships are associated with higher reported adherence to antiretroviral therapy in patients with HIV infection. Journal of General Internal Medicine, 19(11), 1096-1103. https://doi.org/10.1111/j.1525- 
Setoyama, Y., Yamazaki, Y., \& Nakayama, K. (2011). Comparing support to breast cancer patients from online communities and face-to-face support groups. Patient Education and Counseling, 85, e95-e100. https://doi.org/10.1016/j.pec.2010.11.008

Sherbourne, C. D., \& Stewart, A. L. (1991). The MOS social support survey. Social Science \& Medicine, 32(6), 705-714.

Simoni, J. M., Amico, K. R., Pearson, C. R., \& Malow, R. (2008). Strategies for promoting adherence to antiretroviral therapy: A review of the literature. Current Infectious Disease Reports, 10(6), 515-521. https://doi.org/10.1007/s11908-0080083-y

Simoni, J. M., Huh, D., Frick, P. A., Pearson, C. R., Andrasik, M. P., Dunbar, P. J., \& Hooton, T. M. (2009). Peer support and pager messaging to promote antiretroviral modifying therapy in Seattle: A randomized controlled trial. Journal of Acquired Immune Deficiency Syndromes, 52(4), 465-473. https://doi.org/10.1097/QAI.0b013e3181b9300c

Singh, S., Mitsch, A., \& Wu, B. (2017). HIV care outcomes among men who have sex with men with diagnosed HIV infection - United States, 2015. Morbidity and Mortality Weekly Report, 66(37), 969-974.

Tanis, M. (2008). Health-related on-line forums: What's the big attraction? Journal of Health Communication, 13(7), 698-714. https://doi.org/10.1080/10810730802415316

Thompson, M. A., Mugavero, M. J., Amico, K. R., \& Cargill, V. A. (2012). Guidelines for improving entry into and retention in care and antiretroviral adherence for persons with HIV: Evidence-based recommendations from an International Association of Physicians in AIDS Care panel. Annals of Internal Medicine, 156(11), 817-833. https://doi.org/10.7326/0003-4819-156-11-201206050-00419

White House Office of National AIDS Policy. (2015). National HIV/AIDS strategy for the United States: Updated to 2020. Washington, D.C.

Woodward, E. N., \& Pantalone, D. W. (2012). The role of social support and negative affect in medication adherence for HIV-infected men who have sex with men. Journal of the Association of Nurses in AIDS Care, 23(5), 388-396. 
https://doi.org/10.1016/j.jana.2011.09.004 
Table 1. Participant characteristics $(n=202)$

\begin{tabular}{|c|c|}
\hline Demographics & $\mathrm{n}(\%)$ or Mean \pm SD \\
\hline Age & $40.1 \pm 10.8$ \\
\hline \multicolumn{2}{|l|}{ Race } \\
\hline African American or Black & $123(60.9)$ \\
\hline American Indian / Alaska Native & $1(0.5)$ \\
\hline Asian & $1(0.5)$ \\
\hline Native Hawaiian or Pacific Islander & $2(1.0)$ \\
\hline White & $54(26.7)$ \\
\hline More than one race & $12(5.9)$ \\
\hline Not Reported & $9(4.5)$ \\
\hline Hispanic & $62(30.7)$ \\
\hline $\begin{array}{l}\text { Highest Level of Education Completed } \\
\text { High School or Less } \\
\text { Some college, Associates Degree, or Technical Degree } \\
\text { College, Post Graduate, or Professional Degree } \\
\text { Not Reported }\end{array}$ & $\begin{array}{l}59(29.2) \\
90(44.6) \\
52(25.7) \\
1(0.5)\end{array}$ \\
\hline \multicolumn{2}{|l|}{ Employment } \\
\hline Full-Time & $41(20.3)$ \\
\hline Part-Time & $45(22.3)$ \\
\hline Unemployed & $77(38.1)$ \\
\hline Disabled & $35(17.3)$ \\
\hline Retired & $2(1.0)$ \\
\hline Not Reported & $2(1.0)$ \\
\hline \multicolumn{2}{|l|}{ Social Support Scale } \\
\hline Emotional support & $65.0 \pm 29.1$ \\
\hline Affectionate support & $63.2 \pm 33.0$ \\
\hline Tangible support & $52.1 \pm 35.2$ \\
\hline Social interaction support & $65.8 \pm 30.5$ \\
\hline Overall social support & $61.9 \pm 28.0$ \\
\hline \multicolumn{2}{|l|}{ Viral Load $(<20$ copies $/ \mathrm{mL})$} \\
\hline Detectable & $74(36.6)$ \\
\hline Undetectable & $127(62.9)$ \\
\hline Not Reported & $1(0.5)$ \\
\hline
\end{tabular}


Table 2. Example and frequency of social support codes

\begin{tabular}{|c|c|c|}
\hline & Providing social support $(\mathrm{n}=121)$ & Seeking social support $(n=120)$ \\
\hline $\begin{array}{l}\text { Emotional } \\
(\mathrm{n}=137)\end{array}$ & $\begin{array}{l}\mathrm{n}=58 ; \text { Hang in there all } \\
\text { relationships have that give and } \\
\text { take and sometimes it can be } \\
\text { hard cause you may feel at times } \\
\text { you are taking to much. If you } \\
\text { can take the HIV status of you } \\
\text { both out of the picture and just } \\
\text { deal with the love this guy is } \\
\text { showing you may open up more } \\
\text { room for a comforting relation. } \\
\text { Just live and enjoy each other } \\
\text { especially as this guy wants to be } \\
\text { with you regardless of your HIV } \\
\text { status. You have got yourself a } \\
\text { good guy. (Black, } 49 \text {, comment) }\end{array}$ & $\begin{array}{l}\mathrm{n}=79 ; \text { Morning Fam! I need an } \\
\text { important suggestion for my } \\
\text { life... I am pretty sure if this } \\
\text { weekend I go to his place we } \\
\text { would definitely go crazy in bed. } \\
\text { I want to know how should I } \\
\text { bring up this topic before the } \\
\text { weekend. I am little afraid to } \\
\text { know his thoughts on being poz. } \\
\text { Also if I plan on telling him how } \\
\text { can I be honest when it comes to } \\
\text { express? I need the right words } \\
\text { so there is less chance for a } \\
\text { heartbreak? Any help would be } \\
\text { appreciated. Thank you guys } \\
\text { (Asian, 27, post) }\end{array}$ \\
\hline $\begin{array}{l}\text { Informational } \\
(\mathrm{n}=121)\end{array}$ & $\begin{array}{l}\mathrm{n}=69 ; \text { Turn of the TV one hour } \\
\text { before bed. Don't use your phone } \\
\text { or any screen device before bed. } \\
\text { Have a Chamomile tea (make the } \\
\text { tea yourself in a quite } \\
\text { environment). Make sure your } \\
\text { bed place is clean and with good } \\
\text { smell. Make sure the place is } \\
\text { quite and dark. Listen to some } \\
\text { meditation app when you are in } \\
\text { bed. FOCUS on resting your } \\
\text { mind. Tell yourself you are going } \\
\text { to sleep tonight... Sweet Dreams. } \\
\text { (Black, } 47, \text { comment) }\end{array}$ & $\begin{array}{l}\mathrm{n}=52 ; \text { Today I was feeling a bit } \\
\text { down. It was hard to get the day } \\
\text { going. I went to the gym and got } \\
\text { my energy back. Do you ever just } \\
\text { have a hard time getting things } \\
\text { going in the morning. If so what } \\
\text { do you do to pump yourself up? } \\
\text { (Black, } 48, \text { post). }\end{array}$ \\
\hline
\end{tabular}

* Column totals are less than the sum of cell values as more than one type of social support could be provided or sought in the same message. 
Table 3. Frequency, definition, and example of adherence, treatment, and healthcare codes and sub-codes

\begin{tabular}{|c|c|c|}
\hline Codes (n) & $\begin{array}{l}\text { Sub-codes } \\
(\mathrm{n}, \%)^{1}\end{array}$ & Definition/Example \\
\hline \multirow{4}{*}{$\begin{array}{l}\text { Adherence } \\
\text { (54) }\end{array}$} & & Adhering to medication regimen or taking medication \\
\hline & $\begin{array}{l}\text { Adherence } \\
\text { problems } \\
(13 ; 24 \%)\end{array}$ & $\begin{array}{l}\text { Challenges faced in taking treatment including any } \\
\text { external factors } \\
\text { Time for my meds. But I'm out and I don't have a bottle of } \\
\text { water. It's the opposite of the problem of finding a } \\
\text { bathroom when you need one. LOL (White, 54, comment) }\end{array}$ \\
\hline & $\begin{array}{l}\text { Adherence } \\
\text { strategies } \\
(27 ; 50 \%)\end{array}$ & $\begin{array}{l}\text { Ways to help with treatment adherence or not to forget to } \\
\text { take medication } \\
\text { I have to take my pill bottle and put it in a different place } \\
\text { to remind me to take my meds and then return it to where I } \\
\text { original store it or else my mind will obsess about whether } \\
\text { I've taken my meds or not. (Black, 44, comment) }\end{array}$ \\
\hline & $\begin{array}{l}\text { Other } \\
\text { adherence }^{2} \\
(19 ; 35 \%)\end{array}$ & $\begin{array}{l}\text { Content about adherence that was not related to a strategy } \\
\text { or problem } \\
36 \text { yrs (+) and } 20 \text { yrs on ARV's I must say I'm so tired of } \\
\text { taking pills but I know if I stop I will no long have a story } \\
\text { to tell cause I will no longer be here......... (Black, 51, post) }\end{array}$ \\
\hline \multirow[t]{6}{*}{$\begin{array}{l}\text { Treatment } \\
(93)\end{array}$} & & $\begin{array}{l}\text { Any discourse around any type of treatment/medication } \\
\text { including progress in treatment regimens }\end{array}$ \\
\hline & $\begin{array}{l}\text { Labs } \\
(12 ; 13 \%)\end{array}$ & Content about lab results as related to treatment progress \\
\hline & & $\begin{array}{l}\text { Woke up to fantastic news... Official test results came } \\
\text { in... OFFICIALLY Undetectable and my CD } 4 \text { went from } \\
179 \text { to } 612 . . . \text { I hope everyone has a beautiful day... (White, } \\
40, \text { post) }\end{array}$ \\
\hline & $\begin{array}{l}\text { Side } \\
\text { effects } \\
(24 ; 26 \%)\end{array}$ & Content specific to treatment side effects \\
\hline & & $\begin{array}{l}\text { Genvoya here too. In the beginning I was always in the } \\
\text { bathroom ughhhh. From time to time now my stomach acts } \\
\text { up but it's one of the more manageable side affects. Been } \\
\text { on it almost a year now. It gets easier. (White, } 29 \text {, } \\
\text { comment) }\end{array}$ \\
\hline & $\begin{array}{l}\text { Medication } \\
\text { change } \\
(22 ; 24 \%)\end{array}$ & $\begin{array}{l}\text { Content about changing type of medication or the desire to } \\
\text { change medication }\end{array}$ \\
\hline
\end{tabular}




\begin{tabular}{|c|c|c|}
\hline & & $\begin{array}{l}\text { Well... about a week after switching meds and no side } \\
\text { effects. Have to say that Tivicay and Descovy are not so } \\
\text { bad. Now I just take } 2 \text { pills (in the evening) instead of } 7 \\
\text { pills ( } 3 \text { in the morning } 4 \text { in the evening). It's simplified } \\
\text { things for sure. (Multiracial, } 44 \text {, post) }\end{array}$ \\
\hline & $\begin{array}{l}\text { Other } \\
\text { treatment }^{2} \\
(45 ; 48 \%)\end{array}$ & $\begin{array}{l}\text { Content about treatment not related to labs, side effects, or } \\
\text { medication change }\end{array}$ \\
\hline & & $\begin{array}{l}\text { Ifeel anxiety about the future of HIV healthcare under } \\
\text { trump's administration.i don't know how repealing } \\
\text { Obamacare will affect me directly but I'm worried that my } \\
\text { access to meds will go away.do you feel the same. (Black, } \\
26, \text { comment) }\end{array}$ \\
\hline \multirow[t]{4}{*}{$\begin{array}{l}\text { Healthcare } \\
(88)\end{array}$} & & $\begin{array}{l}\text { Content about healthcare and the healthcare system, } \\
\text { including health system issues }\end{array}$ \\
\hline & $\begin{array}{l}\text { Healthcare } \\
\text { provider } \\
(60 ; 70 \%)\end{array}$ & $\begin{array}{l}\text { Content about healthcare provider or discussion around } \\
\text { interactions with healthcare provider }\end{array}$ \\
\hline & & $\begin{array}{l}\text { Your provider served many patients well and that was her } \\
\text { passion in her field. Know that she too was subject to } \\
\text { human outcome and has gone to a restful place. (Black, } \\
59, \text { post) }\end{array}$ \\
\hline & $\begin{array}{l}\text { Other } \\
\text { healthcare } \\
(28 ; 30 \%)\end{array}$ & $\begin{array}{l}\text { Content about healthcare not related to healthcare provider } \\
\text { I am coughing like crazy! My xrays came in clear so now I } \\
\text { get to freak out for a week until I figure out what to do } \\
\text { (Multiracial, } 47, \text { post) }\end{array}$ \\
\hline
\end{tabular}

${ }^{1}$ Percentages can be $>100 \%$ as messages can be assigned more than one sub-code. ${ }^{2}$ Not pre-determined in the codebook; a signifier for when a message was not assigned a sub-code related to the code. 